\title{
Antidepressant Potentials of Aqueous Extract of Voacanga africana stept. ex Eliot (Apocynaceae) Stem Bark
}

\author{
Tunde A. Owolabi ${ }^{1,2^{*}}$, K.C. Ezenwa ${ }^{1}$, E. Amodu ${ }^{1}$, O.C. Iyoriobhe ${ }^{1}$, P.C. Okubor ${ }^{3}$, \\ D.P. Aigbe ${ }^{1,4}$ and J.I. Okogun ${ }^{1,4}$ \\ ${ }^{1}$ Research Unit, Paxherbal Clinic and Research Laboratories, Edo state, Nigeria \\ ${ }^{2}$ Pharmacognosy department, University of Benin, Benin City, Edo State, Nigeria \\ ${ }^{3}$ Department of Biology, College of Education, Agbor, Delta state, Nigeria \\ ${ }^{4}$ Department of Botany, Ambrose Alli University, Ekpoma, Edo State \\ *Corresponding author
}

\section{A B S T R A C T}

\begin{tabular}{|l|}
\hline Ke y w o r d s \\
Voacanga africana, \\
Antidepressant, \\
Forced swim test, \\
Tail suspension test, \\
Phytochemicals \\
\hline Article Info \\
\hline $\begin{array}{l}\text { Accepted: } \\
\text { 20 November } 2019 \\
\text { Available Online: } \\
\text { 10 December } 2019\end{array}$ \\
\hline
\end{tabular}

A large number of the world's population suffer from depression and anxieties at some points in their life time, the sufferers are however sceptical about the available orthodox drugs largely because of side effects, cost and availability. This present study was aimed at evaluating the antidepressant potentials of Voacanga africana to query its ethno medicinal claim. The extract of the stem-bark of the plant was screened for its phytochemical composition, and antidepressant potentials assessed using forced swimming test (FST) and tail suspension test (TST). The results revealed presence of abundant alkaloids, but traces of saponin, terpenoid, cardiac glycosides with a meaningful antidepressant potentials at doses of 100 and $200 \mathrm{mg} / \mathrm{kg}$ by reducing the immobility duration in FST $(46.19 \pm 1.212$ and $23.96 \pm 1.14$ compared to the negative control $79.06 \pm 0.16$ and positive control imipramine $24.13 \pm 0.405$ ), also increasing the swimming duration from $159 \pm 0.416$ of the negative control to $187.91 \pm 0.516$ and $217.24 \pm 1.132$ seconds respectively. Similar trend was observed in the TST, where the immobility duration was reduced from $183.207 \pm 5.157$ (negative control) to $98.62 \pm 0.347$ and $75.51 \pm 1.366$ for 100 and $200 \mathrm{mg} / \mathrm{kg}$ test drug compared to $62.77 \pm 0.426 \mathrm{secs}$ (positive control). The ethno-medicinal claim of this plant is hereby justified.

\section{Introduction}

Medicinal plants may be considered nature's natural wonder drugs. Since the past decade, traditional medicine has become a topic of global importance in view of its vast potentials and the critical role it plays in healthcare delivery, especially in the urban and rural areas where the larger percentage of the population resides (Anselm, 2006). In many African countries especially in sub Saharan Africa, it is estimated that about $80 \%-85 \%$ of the population utilize/depend on traditional medicine especially at primary health-care level [Nigeria Natural Medicine Development Agency, (NNMDA) 2009]. Thousands of 
plants have been reported for their therapeutic effects against several illnesses ranging from cancer (Rajandeep Kaur et al., 2011) to stress (Tunde A Owolabi et al., 2019).

Voacanga africana is a mesophytic, sapwoody, perennial shrub of the primary and secondary forest, within the Tropical Rain Forest and the Guinea Savannah woodland belt (Christopher and Nkechi, 2010). A mature $V$. africana crop dose not grow more than 10 $\mathrm{m}$ height, lowly branched, stem, with smooth, grayish white bark. Slash exudes milky latex. Leaves have simple, petiolate and decussately arrangement. Depression is becoming one of the most widely growing mental illnesses in humans affecting millions of individual every year (Marcus et al., 2012). In South Asia, including India, more than $50 \%$ of all the mental health related DALYs are related to depression (Baingana et al., 2015).

Lately, alternative medicines and/or nutraceuticals have been promoted for treating depression and have found better patient acceptability due to lesser side effects, easy availability and lower cost (Thillaivanan and Samraj, 2014). Many herbal alcoholic extracts of plants such as Centella aciatica, Hibiscuss tilaceous, Moringa olifera have shown antidepressant potential in experimental mouse model (Kaur et al., 2015). Many plant products and botanicals such as Foeniculum vulgare (fennel) fruit (Singh, Sunil and Rana, 2013), Phyllantus amanus (Wasnik, Singh and Alli, 2014), Passiflora foetida, popularly known as stinking passion flower (Santosh et al., 2013).

\section{Materials and Methods}

\section{Plant collection and processing}

Stem bark of $V$. africana (Apocynaceae) was collected within the localities of Ewu, EwuEsan, Edo state of Nigeria in March 2016 and authenticated at the Paxherbal Clinic and Research Laboratories herbarium where a sample specimen was kept with index number $\mathrm{PAX} / \mathrm{H} / 2051$. The plant material was chopped, rinsed under running tap water to remove foreign objects, dried and pulverised into fine powder. $2 \mathrm{~kg}$ of the pulverised $V$. africana was macerated in $5 \mathrm{~L}$ of water, filtered and the filtrate concentrated into a brown syrupy mass on a water bath at temperature of $70{ }^{\circ} \mathrm{C}$ for 4 days. It was further dried in a hot air oven at $50{ }^{\circ} \mathrm{C}$ for two days and the semi-solid extract kept in a refrigerator for the analysis.

\section{Experimental animals}

Albino Wistar rats of both sex (150-200 g) and Albino male Swiss mice (22-25g) were obtained from Paxherbal animal house, EwuEsan, Edo state, Nigeria. The animals were kept in cages under standard laboratory conditions (Relative humidity 55-65\%, room temperature $25.0 \pm 2{ }^{\circ} \mathrm{C}$ and $12 \mathrm{~h}$ light/dark cycle) for two weeks prior to experimentation for adaptation with the laboratory conditions.

Animals were fasted overnight with free access to water prior to each experiment. Fourteen hours before the start of the experiment the animals were isolated and fed only with water libitum. Ethical approval was sorted and the experiments were performed in accordance with the rules of Institutional Animals Ethics Committee.

\section{Experimental animal grouping}

Five groups ( $\mathrm{n}=6$ for each group) were used: Group 1 received $1 \mathrm{ml}$ normal saline as the negative control, Group 2 received $1 \mathrm{ml}$ Imipramine $(30 \mathrm{mg} / \mathrm{kg})$ as positive control. Group 3, 4 and 5 received aqueous extract of varying doses (50, 100, and $200 \mathrm{mg} / \mathrm{kg}$ ) respectively. 


\section{Chemicals}

All chemical used except Imipramine hydrochloride (Sigma Aldrich, St. Louis, USA) were obtained from Paxherbal Clinic and Research Laboratories and are of analytical grade.

\section{Phytochemical screening}

Preliminary phytochemical screening of the powdered stem bark was performed for the presence of secondary metabolites using standard methods of John et al., (2014).

\section{Forced swimming test}

The forced swimming test was performed according to the method of Hritcu et al., (2012) to evaluate the antidepressant effect of $V$. africana in rats. Animals were placed in cylindrical containers $(10 \times 45 \mathrm{~cm})$ which were filled with water at $24-25{ }^{\circ} \mathrm{C}$ with a 30 $\mathrm{cm}$ depth and behaviours were monitored (Fig. 1). Normal saline and aqueous extract of $V$. africana bark were administered orally while imipramine was administered i.p 30 min prior to the test session. The duration of test was 6 min. After 2 min, immobility and swimming time was measured during the last $4 \mathrm{~min}$. Immobility was assigned when no additional activity was observed other than that required to keep the animal's head above the water and swimming time assigned when animal did active movement of extremities and circling in the container.

\section{Tail suspension test}

The tail suspension test (TST) was performed according to the method described by Steru $e t$ al. (1985). The mice were individually suspended $60 \mathrm{~cm}$ above the surface of table with an adhesive tape placed $1 \mathrm{~cm}$ away from the tip of the tail (Fig. 2). Immobility duration was recorded for the last 5 min during 6 min by observers blind to the treatment conditions. Mice were considered immobile only when they hung passively and were completely motionless. Saline and aqueous extract of $V$. africana were administered orally while imipramine $(30 \mathrm{mg} / \mathrm{kg})$ was administered via intraperitoneal one hour prior to test.

\section{Statistical analysis}

The results were expressed as mean \pm S.E.M. The statistical significance was determined by One-Way Analysis of Variance (ANOVA). Followed by T-test $\mathrm{P}<0.05$ was considered to be statistically significant.

\section{Results and Discussion}

\section{Phytochemical screening}

The phytochemical screening results revealed the presence of some bioactive compounds; abundant alkaloids, but traces of saponin, terpenoid, cardiac glycosides as presented in table 1.

\section{Effects on immobility and swimming times in rat using FST}

The effect of Imipramine (30mg/kg i.p) and the aqueous extract of $V$. africana bark on immobility and swimming time in FST in rats as presented figure 1 and 2 . The result obtained in this present study revealed an impressive antidepressant effect on rat and mice. Both TST and FST models of depression are widely used to screen new antidepressant drugs (Hritcu et al., 2012), which are quite sensitive and relatively specific to all major classes of antidepressant drugs. With assessment in forced swimming test (FST), there was significant difference in immobility between low and high doses of the extract $(\mathrm{p}<0.05)$ with the most active dose of $200 \mathrm{mg} / \mathrm{kg}(23.96 \pm 1.14)$ comparable to the standard drug Imipramine at $30 \mathrm{mg} / \mathrm{kg}$ 
$(24.13 \pm 0.405)$ and negative control group $(79 \pm 0.042)$, while 50 and $100 \mathrm{mg} / \mathrm{kg}$ displayed relative activities of $58.44 \pm 0.511$ and $46.19 \pm 1.212$. Also, the swimming times were significantly extended: (negative control group
$159 \pm 0.416), \quad 200 \mathrm{mg} / \mathrm{kg} \quad$ test drug (217.24 \pm 1.132$)$ comparable to the standard drug Imipramine at $30 \mathrm{mg} / \mathrm{kg}(214.81 \pm 0.2582)$, while 50 and $100 \mathrm{mg} / \mathrm{kg}$ displayed relative activities of $176.32 \pm 0.197$ and $187.91 \pm 0.516$.

Table.1 Qualitative Phytochemical evaluation results of bark aqueous extract of $V$. africana

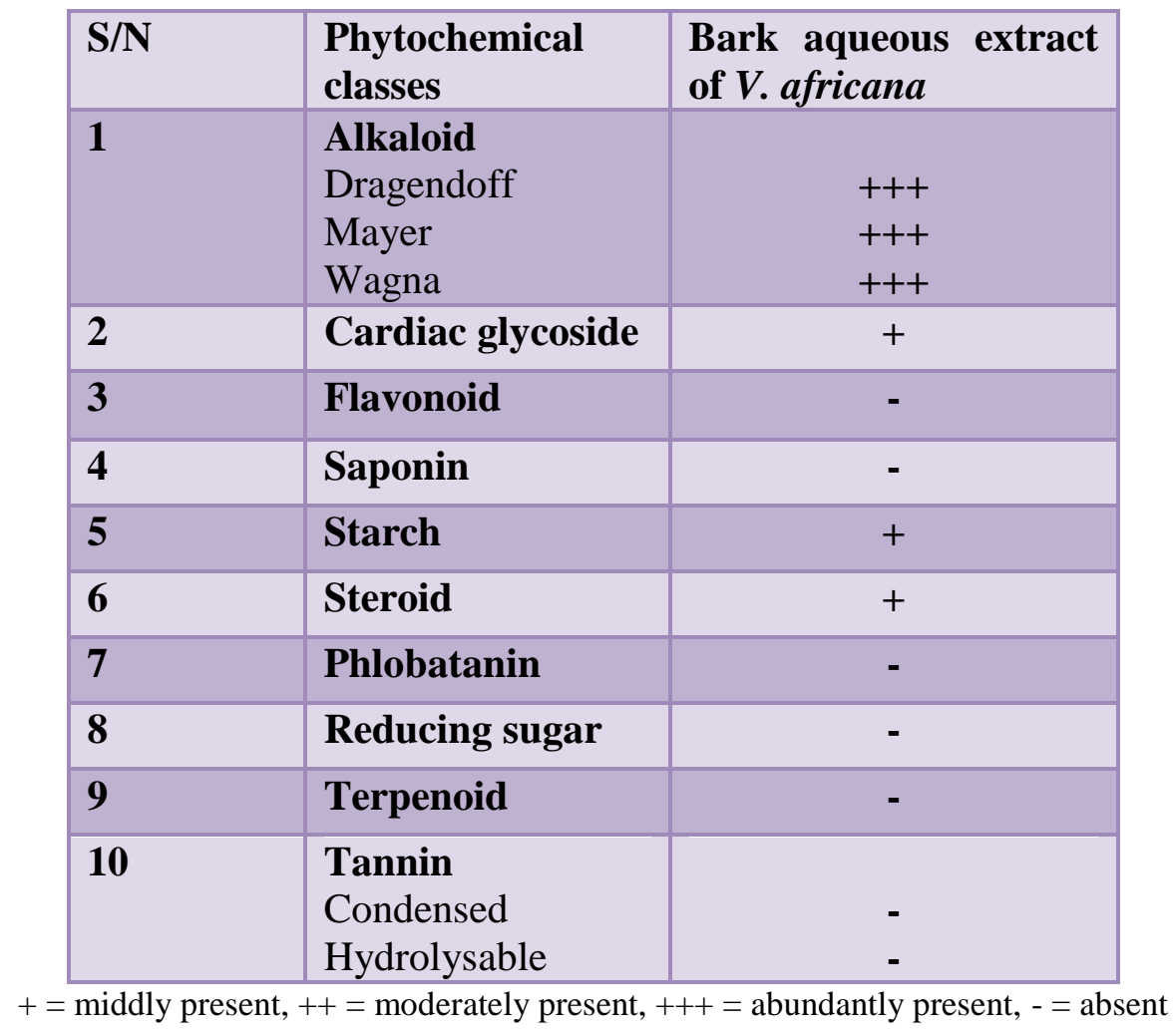

Fig.1 The effect of imipramine and $V$. africana on swimming times in rat using forced swim test

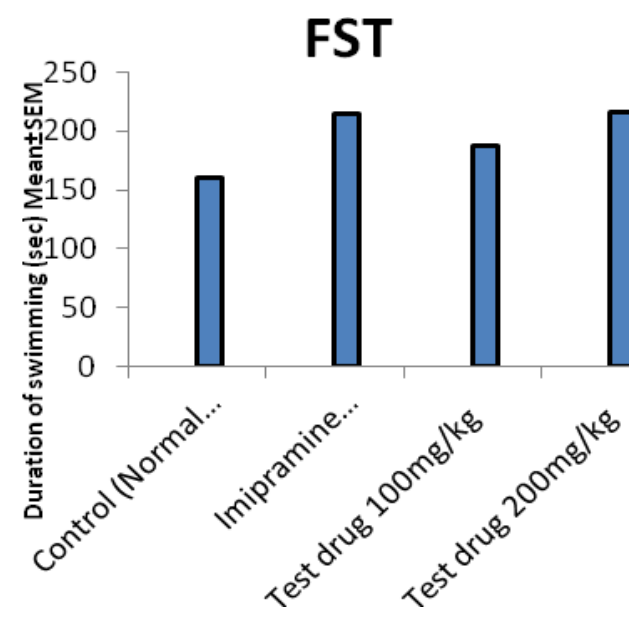


Fig.2 The effect of imipramine and $V$. africana on immobility times in rat using forced swim test

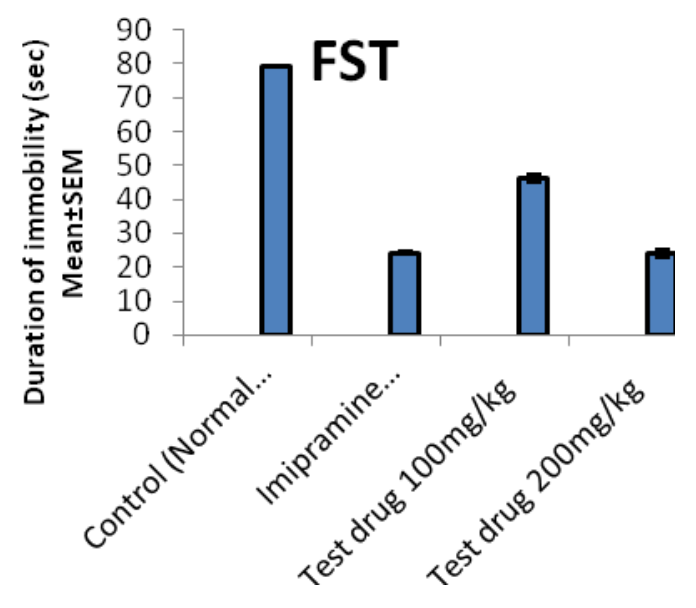

Fig.3 Effect of imipramine and V. africana bark extract on tail suspension model in mice
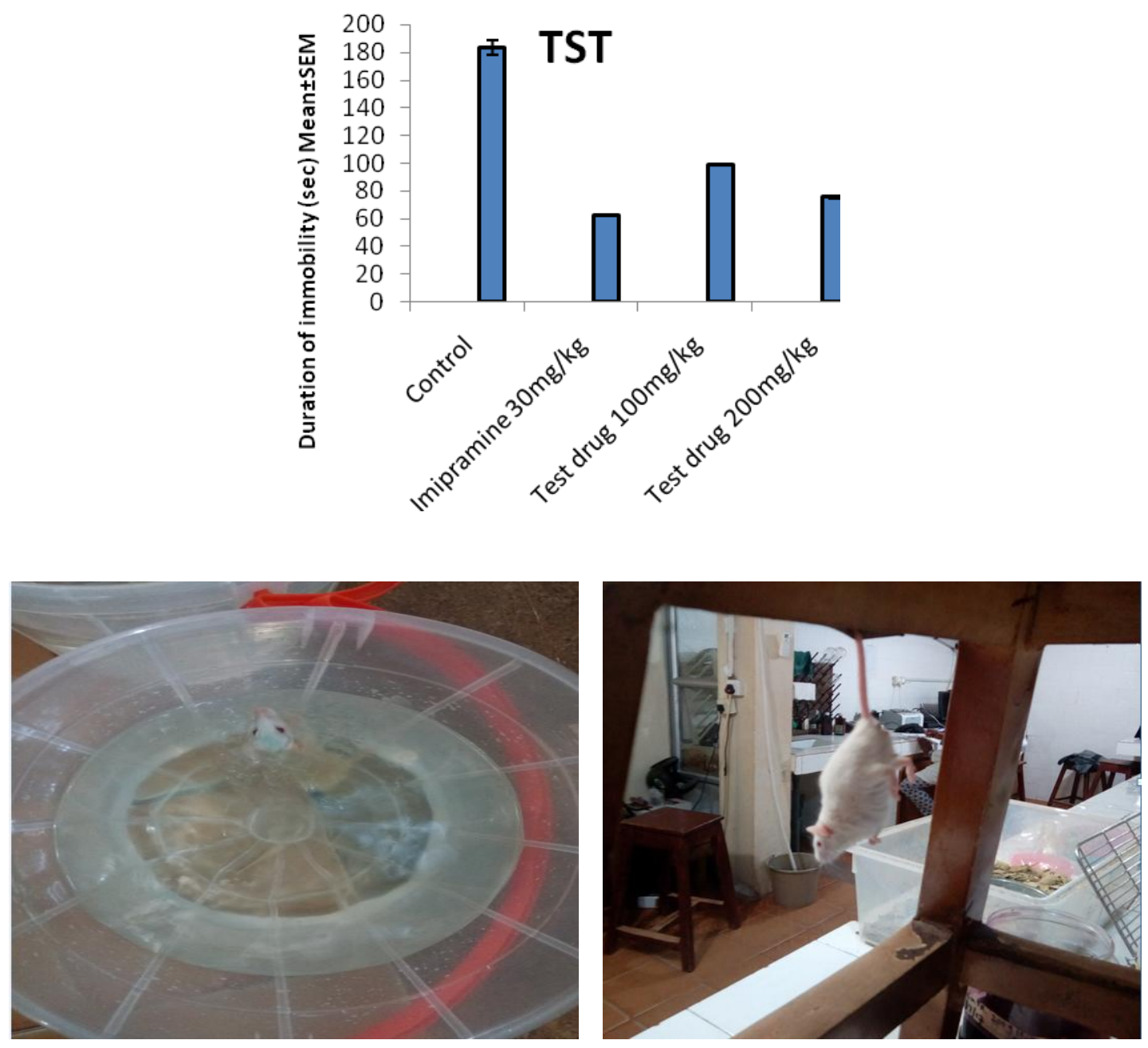
The effect of imipramine and $V$. africana on TST

The effect of Imipramine (30mg/kg i.p) and the aqueous extract of $V$. africana bark on tail suspension test in mice (TST) as shown in figure 3, administration of Imipramine (i.p) and the oral administration of the three different doses of aqueous extract $(50,100$ and $200 \mathrm{mg} / \mathrm{kg}$ ) of $V$. africana is significant at $\mathrm{p}<0.05$ by decreasing immobility (62.77 $\pm 0.426, \quad 165.3 \pm 19.3, \quad 98.62 \pm 0.347$, $75.51 \pm 1.366$ as compared with the control group (183.207 \pm 5.157$)$. The extract was able to induce antidepressant effects after oral administration of varying doses of $V$. africana bark extract with the highest dose (200 $\mathrm{mg} / \mathrm{kg}$ ) showing the highest immobility. The observed activity could be a justification for its consideration as an analgesic according to James et al., (2007), as well as in the treatment of heart arches. Hence, from the above results it can be seen that among the three doses of the extract used, the most effective dose for antidepressant action using forced swim test is $200 \mathrm{mg} / \mathrm{kg}$ of $V$. africana. However, since $100 \mathrm{mg} / \mathrm{kg}$ also showed significant antidepressant activities, it will be preferred to the higher dose because of high level of alkaloid which can have some level of toxicity.

In conclusion, the extract showed impressive antidepressant potential and this present study, as far as is known, is the first report of the antidepressant activities of the extracts of $V$. africana. This also justifies the ethnomedicinal usage of the plant.

\section{Acknowledgement}

All adoration belongs to Almighty God, but in the appreciation of men is the gratitude to God, we appreciate all our Teachers and mentors for their useful contribution to the making of this work, special gratitude to the management of Pax Herbal Clinic and Research Laboratories for all the support rendered.

\section{References}

Anselm, A. (2006). Nature Power: Christian Approach to Herbal Medicine. Don Bosco Training Center, School of PTP, Akure. pp 10-30.

Baingana, al'Absi FM, Becker AE, Pringle B (2015). Global research challenges and opportunities for mental health and substance-use disorders. Nature, 527: S172-S177.

Christopher MD, Nkechi EO (2010). In vitro Antimicrobial Assay and Phytochemical Analysis of Ethanolic Extracts of Voacanga africana Seeds. Journal of American Science. 6(6).

Hritcu L, Cioanca O, Hancianu M (2012). Effects of lavender oil inhalation on improving scopolamine-induced spatial memory impairment in laboratory rats. Phytomedicine. 19:529-534.

James E. Simon, Adolfina R. Koroch, Dan Acquaye, Elton Jefthas, Rodolfo Juliani, and Ramu Govindasamy (2007). Medicinal Crops of Africa. ASHS Press, Alexandria, VA.

John, B, Sulaiman CT, George S, Reddy VRK (2014). Total phenolics and flavonoids in selected medicinal plants from Kerala. Int. J. Pharm. Pharmaceut. Sci., 6: 406-408.

Kaur, Invally GM, Sanzagiri R, Buttar HS (2015). Evaluation of the antidepressant activity of Moringa oleifera alone and in combination with fluoxetine. J. Ayurveda Integr. Med., 6: 273-279.

Lucien Steru, Raymond Chermat, Bernard Thierry and Pierre Simon (1985). The tail suspension test: A new method for screening antidepressants in mice. Psychopharmacology (1985) 85:367370. 
Marcus M, Yasamy MT, Van Ommeren M, Chisholm D, Saxena S (2012). Depression: A global public health concern.

Nigeria Natural Medicine Development Agency, (NNMDA) (2009). Federal Ministry of Science and Technology 9, Kofo Abayomi Street, Victoria Island, Lagos, Nigeria. p. 1-49.

Rajandeep Kaur, Jagpreet Singh, Gagandeep Singh, Harpreet kaur (2011). Anticancer plants: A Review. Jounal of Natural Product and Plant Resources. 1 (4): 131-136.

Santosh P, Venugopl R, Nilakash AS, Kunjbihari S, Mangala L (2013). Antidepressant activity of methanolic extract of Passiflora foetida leaves in mice. International Journal of Pharmaceutical Sciences Review and Research. 112-115.

Singh JN, Sunil K, Rana AC (2013). Antidepressant activity of methanolic extract of Foeniculum vulgare (Fennel) fruits in experimental animal models. Jornal of Applied Pharmaceutical Science. 3:065-070.

Thillaivanan S, and Samraj K (2014). Challenges, Constraints and Opportunities in Herbal Medicines - A Review. International Journal of Herbal Medicine. 2(1): 21-24.

Tunde A. Owolabi, K.C. Ezenwa, E.Y. Olayioye, O.C. Iyorhibe, E. Amodu, O.F. Aferuan, P.C. Okubor, B.A. Ayinde and Okogun, J.I. 2019. Adaptogenic (Anti-Stress) Effect of Aqueous Musanga cecropioides (Urticaceae). Int.J.Curr.Microbiol.App. Sci. 8(10): 2558-2565. doi: https://doi.org/10.20546/ijcmas.2019.81 0.296 .

Wasnik U, Singh V, Alli M (2014) Evaluation of the antidepressant effects of Phyllanthus amarus in Mice. International Journal of Pharmaceutical Sciences Review and Research. 06:2629.

\section{How to cite this article:}

Tunde A. Owolabi, K.C. Ezenwa, E. Amodu, O.C. Iyoriobhe, P.C. Okubor, D.P. Aigbe and Okogun, J.I. 2019. Antidepressant Potentials of Aqueous Extract of Voacanga africana stept. ex Eliot (Apocynaceae) Stem Bark. Int.J.Curr.Microbiol.App.Sci. 8(12): 2623-2629. doi: https://doi.org/10.20546/ijcmas.2019.812.306 